\title{
South African official quits ministry post
}

[CAPE TOWN] The top government official in South Africa's Department of Arts, Culture, Science and Technology resigned last week following reported disputes with his minister, Lionel Mtshali, and one of his deputies, Musa Xulu, over the use of government funds.

Roger Jardine, the department's respected director-general, is said to have been worried by public perceptions that Xulu and Mtshali were attempting to use the department to advance the political interests of the Inkatha Freedom Party (IFP), which partners the African National Congress (ANC) in the coalition government.

In particular, the department has been criticized for spending almost a million rand (US\$178,000) on a feast for 10,000 guests to be held next month at the unveiling of a new monument to the Battle of Blood River, where the Voortrekkers and Zulus clashed in 1838 (the monument itself is costing R2.5 million).

Most of those invited are local residents and, with an election due next May, this has been interpreted as an attempt to curry favour with the IFP's political base in rural Kwazulu-Natal.

Mtshali was unavailable for comment this week. But his press officer, Frans Basson, confirmed that Mtshali and Jardine held a meeting earlier this month after which Jardine wrote to the minister requesting that his five-year contract be terminated on 31 December - 13 months early.

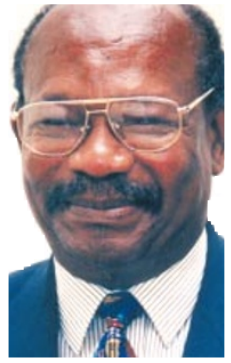

Mtshali: concern

over use of funds.
Jardine, 33, a medical physicist who was the youngest director-general of a government department when he was appointed in February 1995, issued a statement saying that "his reasons for leaving were both personal and professional". But he is understood to have had an uneasy relationship with Mtshali since the latter took over as minister from Ben Ngubane just over two years ago. Jardine was formerly head of the ANC's science and technology division at its headquarters at Shell House in Johannesburg (see Nature 373, 651; 1995).

The ministerial portfolio is one of three in the coalition government allocated to the IFP. But Mtshali, a former schoolmaster turned inspector of schools, appears less pragmatic than his predecessor, who enjoyed a good working relationship with Jardine before moving to Kwazulu-Natal to become provincial premier.

Jardine's is the third departure of a director-general from central government in the past six months. Olive Shisana, who left the health ministry to take up a senior post at the World Health Organization in Geneva, last week openly blamed the Minister of Health, Nkosazana Zuma, for spending R14 million on a controversial AIDS play, 'Sarafina', with- out her approval or following correct tender procedures (see Nature 386, 6; 1997).

The government's anti-corruption unit issued summonses on several parties earlier this month, including both Zuma and Shisana, who are liable for the recovery of outstanding funds for this project.

Jardine's departure has been lamented in research circles. Rolf Stump, deputy vicechancellor at Stellenbosch University and former president of the Human Sciences Research Council, said that Jardine's spearheading of the transformation of the country's science and technology system "has been one of the most successful systematic transformations in our society".

Deputy president Thabo Mbeki is expected to win next year's elections and to make government more streamlined. The Arts, Culture, Science and Technology ministry has been identified by the presidential review commission as a candidate for dissolution.

If dissolved, its functions are likely either to be incorporated into the Department of Education, or to be split, with science and technology being moved to the Department of Trade and Industry under the highlyregarded minister Alec Erwin.

Ironically, however, the department might survive as a result of the need for an apparently innocuous cabinet portfolio which can be allocated to the IFP, which appears set to remain in a coalition government with the ANC despite questions about its administrative abilities.

Michael Cherry

\section{Budget cuts mean tough times ahead for Brazilian researchers}

[S̃̃O PAULO] The Brazilian government has slightly reduced the severity of cuts being imposed on science in a general restriction on public expenditure designed to cushion the impact of the international financial crisis on the country's economy.

But the cuts, introduced primarily to meet the terms of a loan from the International Monetary Fund (see Nature 395,831 ; 1998), remain severe, and have already generated widespread protests from the scientific community. Many scientists are lobbying their members of Congress, who will vote on the detailed budget proposal on 15 December.

The rectors of the nine universities that perform most of the country's research issued a public protest during a recent meeting in Belo Horizonte. Jacques Marcovitch, rector of the University of São Paulo, the country's largest, is worried because federal finance is an important source of funds for graduate research.

"We risk losing the investment made in recent years, and now face the possibility of compromising basic activities," says Sergio Henrique Ferreira, president of the Brazilian Society for the Development of Science (SBPC).

Overall, the budget of the Ministry of Science and Technology will be cut by 18.7 per cent, or 169.8 million réals (US \$142 million), less than the originally envisaged cut of 907 million réals. Other researchfunding ministries will be affected to varying degrees. For example, the budget of the Ministry of Agriculture will shrink by 17 per cent, and the Ministry of Health will lose about 6.6 per cent.

The science ministry has not yet decided which areas will be affected. Ministry officials say only that existing fellowships will be funded, as these are considered to be equivalent to researchers' salaries, which must not be interrupted. But there are likely to be major cuts in trips to attend scientific meetings abroad, and in the financing of such meetings inside Brazil.

Of greater concern to scientists are the prospects for grants to specific research programmes, such as the competitive Support Programme to Centres of Excellency (Pronex), which is funded by the ministry of science to reward some of the best research groups in the country.

It has already been decided which projects will be funded under Pronex 1 and 2 , but researchers are still waiting for some of the promised grants. There is also worry about the next phase, Pronex 3.

Etelvino Bechara, a chemistry researcher at the University of São Paulo, warns that science in the region will be hurt by any cut in support for the National Council for Scientific and Technological Development, the main federal funding agency. "The difficulties of importing research material will probably increase," he adds.

Many researchers, particularly in areas lacking strong regional science funds, are suffering from cuts imposed earlier this year. "We have several projects paralysed in our university," says Lucio Flavio Moreira, a physiologist at the Federal University of Rio Grande do Norte. Ricardo Bonalume Neto 